University of Nebraska - Lincoln

DigitalCommons@University of Nebraska - Lincoln

Biology of Diorhabda elongata deserticola (Coleoptera: Chrysomelidae), an Asian leaf beetle for biological control of saltcedars (Tamarix spp.) in the United States

\author{
Phil A. Lewis \\ United States Department of Agriculture \\ C. Jack Deloach \\ United States Department of Agriculture \\ Allen E. Knutson \\ Texas A\&M University, a-knutson@tamu.edu \\ James L. Tracy \\ United States Department of Agriculture \\ Thomas O. Robbins \\ United States Department of Agriculture
}

Follow this and additional works at: https://digitalcommons.unl.edu/usdaarsfacpub

Part of the Agricultural Science Commons

Lewis, Phil A.; Deloach, C. Jack; Knutson, Allen E.; Tracy, James L.; and Robbins, Thomas O., "Biology of Diorhabda elongata deserticola (Coleoptera: Chrysomelidae), an Asian leaf beetle for biological control of saltcedars (Tamarix spp.) in the United States" (2003). Publications from USDA-ARS / UNL Faculty. 327. https://digitalcommons.unl.edu/usdaarsfacpub/327

This Article is brought to you for free and open access by the U.S. Department of Agriculture: Agricultural Research Service, Lincoln, Nebraska at DigitalCommons@University of Nebraska - Lincoln. It has been accepted for inclusion in Publications from USDA-ARS / UNL Faculty by an authorized administrator of DigitalCommons@University of Nebraska - Lincoln. 


\title{
Biology of Diorhabda elongata deserticola (Coleoptera: Chrysomelidae), an Asian leaf beetle for biological control of saltcedars (Tamarix spp.) in the United States
}

\author{
Phil A. Lewis, ${ }^{\text {a, }}{ }^{*}$ C. Jack DeLoach, ${ }^{\text {a }}$ Allen E. Knutson, ${ }^{\mathrm{b}}$ James L. Tracy, ${ }^{\mathrm{a}}$ \\ and Thomas O. Robbins ${ }^{\mathrm{a}}$ \\ ${ }^{a}$ United States Department of Agriculture, Agricultural Research Service, Grassland Soil and Water Research Laboratory, \\ 808 E. Blackland Road, Temple, TX 76502, USA \\ ${ }^{\mathrm{b}}$ Texas A\&M University, Research and Extension Center, 17360 Coit Road, Dallas, TX 75252-6599, USA
}

Received 7 January 2002; accepted 18 December 2002

\begin{abstract}
Adults and larvae of Diorhabda elongata Brullé subspecies deserticola Chen feed on the foliage of saltcedars (Tamarix spp.). All three instars are black, the 2nd with an indistinct, and the 3rd with a distinct yellowish lateral stripe; full-grown larvae reach ca. $9 \mathrm{~mm}$ in length and pupate in cells in litter on the ground or a few $\mathrm{cm}$ below the soil surface. Adults are yellowish with two dark brown stripes on each elytron. Duration of the egg averaged 5 days, 1st instar 4.9 days, 2nd instar 4.8 days, 3rd instar 7.4 days, prepupa 4.8 days, and pupa 7.1 days at $24.1^{\circ} \mathrm{C}$. Preoviposition averaged 3.9 days and an average female oviposited over a 12 -day period and laid 194 eggs. Degree-day accumulations for development were 234.2 for the three larval instars and 91.3 for the pupa above a developmental threshold of $12.5^{\circ} \mathrm{C}$. Net reproductive rate $\left(R_{0}\right)$ in the laboratory at $28.6^{\circ} \mathrm{C}$ and on the best Tamarix accession was calculated at 88 , generation time at 37 days, and innate capacity of increase $\left(r_{\mathrm{m}}\right)$ at 0.112 , giving a population doubling time of 6.2 days. In field cages in Colorado, Wyoming, Utah, Nevada, and California, overwintering adults emerged from late April to early May. Adults of the first generation emerged in early to mid-July, and 2nd generation adults emerged from mid-August to early September and overwintered. High populations of larvae developing in field cages caused defoliation, dieback, and sometimes death of the Tamarix trees. At the three study sites in Texas, maximum daylength was $14 \mathrm{~h} 21$ min and larvae exposed to these conditions produced adults in reproductive diapause early in the season and subsequently failed to overwinter. North of $38^{\circ}$ latitude in the United States, populations of $D$. e. deserticola originating from Fukang, China and Chilik, Kazakhstan are active throughout the growing season, successfully overwinter, and are potentially a highly effective control agent for saltcedar.
\end{abstract}

Published by Elsevier Science (USA).

Keywords: Diorhabda elongata deserticola; Chrysomelidae; Biocontrol of weeds; Invasive plants; Tamarix; Reproductive biology; Degree-days; Diapause

\section{Introduction}

Saltcedars are deciduous, small trees or shrubs in the genus Tamarix (Tamaricaceae) that in the United States are highly invasive, exotic riparian weeds. In infested

\footnotetext{
${ }^{*}$ Corresponding author. Present address: USDA-Animal and Plant Health Inspection Service, Pest Survey, Detection and Exclusion Laboratory, Otis ANGB, MA 02542, USA. Fax: 1-508-564-4398.

E-mail address: phillip.a.lewis@aphis.usda.gov (P.A. Lewis).
}

areas, saltcedar often occurs as dense, monotypic thickets 5-7 m high, with 100\% canopy cover. They have attractive, small pink flowers that are insect pollinated and produce small, wind-blown seeds; foliage consists of small, cedar-like bracts. Saltcedars are facultative phreatophytes (deep-rooted perennials deriving water at or just above the water table) that aggressively grow along streams and lakes, out competing and displacing native flora. Water use by these plants is among the highest of all stream-bank species (Johns, 1989). 
Saltcedars are both drought and flood tolerant; taproots extend down $30 \mathrm{~m}$ or more and plants can survive total submergence for up to 70 days (Warren and Turner, 1975). They are capable of utilizing saline groundwater by excreting excess salts through glands in the leaves. The resulting increase in soil surface salinity combines with the very dense canopy and a higher likelihood of fires within stands of saltcedar to kill and eliminate associated cottonwoods, willows, and other native riparian plants. As a result of saltcedar invading riparian ecosystems in the Southwestern United States, populations of several species of birds and fishes are in severe decline and some have become threatened or endangered (Anderson and Ohmart, 1977; DeLoach et al., 2000; Dudley et al., 2000; Hunter, 1984; Tracy and DeLoach, 1999). Recent economic assessments estimate that saltcedars cost the Western United States between $\$ 133$ and $\$ 185$ million each year in lost ecosystem services (Brown et al., 1989; Zavaleta, 2000).

In the United States, saltcedars are fed upon only minimally by native insect herbivores, and only by the more generalist species, although many adult insects visit the flowers. However, one leafhopper (Opsius stactogalus Fieber) (Homoptera: Cicadellidae) and two scale insects (Chionaspis spp.) (Homoptera: Diaspididae) all accidentally introduced from the Old World, occasionally damage Tamarix spp. in the United States, but not enough to reduce stands (DeLoach and Tracy, 1997). Many insects attack saltcedar within its native range in central Asia (Kovalev, 1995; Mityaev, 1958; Sinadsky, 1968), Italy (Zocchi, 1971), Israel (Gerling and Kugler, 1973), Turkey (Pemberton and Hoover, 1980), Pakistan (Habib and Hasan, 1982), and China (DeLoach, unpublished data). Because of the isolated evolution of Tamarix in saline deserts of Asia, and its consequent taxonomic isolation, most of the insects that feed on it also evolved in isolated conditions and do not feed on other plants. More than 200 species of insects probably are sufficiently host-specific to be evaluated for introduction into the United States for biological control (Kovalev, 1995). Because of the lack of herbivores of Tamarix in the United States, biological control through importation of exotic, host-specific herbivores is a potential but unexploited means to suppress saltcedars (DeLoach, 1989; DeLoach et al., 1996).

One of the more promising candidates for biological control is a leaf beetle from central Asia, Diorhabda elongata Brullé subspecies deserticola Chen (Coleoptera: Chrysomelidae) (Kovalev, 1995). This insect has been noted to completely defoliate large areas of saltcedar and aspects of its life history as a pest of Tamarix windbreaks has been reported in Russian and Chinese literature (Bao, 1989; Sha and Yibulayin, 1993; Sinadsky, 1968; Tian et al., 1988). Diorhabda elongata was described by Brullé (1832) and the subspecies deserticola by Chen (1961), but without descriptions or illustrations of the immature stages. Supplementary descriptions and an illustration of adult $D$. elongata from France were provided by Laboissière (1934); illustration of the adult and some larval characters of $D$. elongata, including keys to adults of five Diorhabda species in Russia by Ogloblin (1936); and illustration of the aedeagus and larval characters of $D$. e. deserticola, including keys to adults and larvae of three subspecies in Mongolia by Medvedev and Voronova (1977). Lopatin (1977) recognized seven species of Diorhabda (tribe Galerucini) from Central and Middle Asia and the Mediterranean region. Of these, only $D$. elongata develops on Tamarix and it is restricted to plants in the genera Tamarix and Myricaria. DeLoach et al. (2003) reviewed the literature on host ranges and geographic distributions of the subspecies of $D$. elongata.

Host-range testing of D. e. deserticola has been completed at the USDA-ARS quarantine facilities at Temple, Texas and at Albany, California (DeLoach et al., 2003), including additional testing on Frankenia spp. (Lewis et al., 2003). The USDA-Animal and Plant Health Inspection Service (APHIS) approved this insect for limited field release within cages at 10 locations in six Western states (California, Nevada, Utah, Colorado, Wyoming, and Texas) on 7 July 1999, and issued permits for open-field releases on 16 February 2001. We and our cooperators made the first open-field releases at eight of these approved sites in May and June 2001. This is to be followed by 2 years of field studies at these locations that will assess the effects of biological control on the native flora and fauna. The present paper reports studies of the life history and ecology of D. e. deserticola in the laboratory and in field cages in the United States, and discusses its potential as a biocontrol agent for saltcedar in North America. These results will provide avenues for future investigations into the biology and impact of this species.

\section{Materials and methods}

\subsection{Insect and plant source}

All insects used in both laboratory and field studies originated from adults collected at Fukang, China, with the exception of the Delta, Utah study site where the insects originated from Chilik, Kazakhstan. See DeLoach et al. (2003) for further details of insect and plant taxonomy and identification.

\subsection{Field and laboratory studies}

Duration and characterization of each life stage of D. e. deserticola were determined both outdoors in secure field cages and within the Arthropod Quarantine Facility at the USDA-ARS Grassland, Soil and Water Research 
Laboratory at Temple, Texas. Observations of caged field populations during the growing season varied from weekly to monthly at our research sites in Texas, Colorado, Wyoming, Utah, Nevada, and California. Life stage development of the beetles was monitored and extent of defoliation within the cages was noted. In quarantine at Temple, insects were individually reared on Tamarix foliage within $50 \mathrm{ml}$ clear plastic vials at a relatively constant temperature of $24.1 \pm 2{ }^{\circ} \mathrm{C}$ and a $16: 8$ light:dark photoperiod and observed daily until adult eclosion. Eggs and larval head capsules were measured using a calibrated ocular micrometer mounted in a stereo microscope. Duration of the egg stage was determined by collecting newly laid eggs and observing them twice a day.

\subsection{Degree-days and development time}

Four studies of the rate of larval and pupal development were conducted at our facilities at Temple (August and September 1999) and at Dallas, Texas (October 1999 and June 2000). These tests were done under natural conditions in large outdoor field cages made of $18 \times 14$ mesh, tan-colored Saran screening (PAK Unlimited, Cornelia, Georgia) over an aluminum conduit frame measuring $3 \times 3 \times 2 \mathrm{~m}$ high. Individual neonate larvae ( $n=25$ at Temple; $n=29$ at Dallas) were each placed in a polyester organza mesh bag $(10 \times 22 \mathrm{~cm})$ on saltcedar foliage inside the large cage; the open end of the bag was secured around the stem with a twist tie. Larvae were checked daily for the presence of cast skins and life stage until adult eclosion. All larvae that completed a particular life stage were used to calculate the days of development for that life stage. Temperature was recorded using HOBO recorders (Onset Computer, Pocasset, Massachusetts) placed in the cages from which we determined the average daily temperature. The development rate outdoors was compared to development of 11 individuals that survived to pupal eclosion on T. ramosissima under a constant $24.1 \pm 2{ }^{\circ} \mathrm{C}$ in the quarantine laboratory at Temple in 1992.

Degree-days for development of each stage was calculated based on the mean development times of these five data sets. The equation $C=$ (mean temperature) $K$ was used to calculate degree-day $\left({ }^{\circ} \mathrm{C}\right)$ accumulations during each study, where $K$ is the threshold temperature for development (Arnold, 1960). Accumulated degreedays were calculated using average daily temperatures. The calculated degree-day values for this insect were then used to predict when a beetle generation would emerge at three of the United States research locations and at Fukang, China. Predicted emergence of generations was compared to phenology of caged field populations at Temple and at research sites along the Arkansas River near Pueblo, Colorado, and near Yellowtail Reservoir in the vicinity of Lovell, Wyoming. Development by $D$. e. deserticola in the open field at
Fukang was determined from data given by $\mathrm{Li}$ et al. (2000). Field data were sporadic and the period of adult emergence could not always be determined, in which case the prediction of adult emergence was not made for that generation of insects at that location.

\subsection{Survival, development, and reproductive parameters on Tamarix spp.}

Survival and development of larvae of D. e. deserticola were determined on two accessions of T. ramosissima, old and young foliage of this species, and on foliage of $T$. parviflora, $T$. canariensis, and T. aphylla. These studies were conducted in the laboratory at Temple from July to October 1999 under constant light conditions and temperatures averaging $27.9 \pm 1.4^{\circ} \mathrm{C}$. For each plant treatment, three cohorts of 30-46 neonate larvae were placed within mesh bags, with each cohort reared on an individual plant. Percent survival through adult eclosion within bags (10-11 larvae per bag) was averaged for each cohort. Females that emerged from each test plant were then paired with a male of the same age and maintained as individual pairs in $250 \mathrm{ml}$ yogurt cups on cut foliage from the same plant type. Ovipositing females were monitored daily for egg-laying and longevity; data from both larvae and adults were used to calculate population growth statistics for each treatment. In order to statistically compare net reproductive rate $\left(R_{0}\right)$, mean generation time $(T)$, innate capacity for increase $\left(r_{\mathrm{m}}\right)$, and population doubling time (DT) (Birch, 1948), data from cohorts of 3 to 11 individual females were grouped by test plant for a means analysis.

\subsection{Diapause studies}

Absence of mating and foliage-feeding by adults that had newly emerged in field cages in Temple during late August prompted us to investigate this behavior. Procedures for a set of three tests to study reproductive diapause and dormancy are described below.

In the first test, adults within the outdoor cages that were not laying eggs and that had emerged within the past several days were collected and divided into two equal groups of 26 beetles. On 10 September, one group was placed in the outdoor cage within a small aluminum cage $(51 \times 69 \times 84 \mathrm{~cm})$ containing a potted saltcedar plant and $7 \mathrm{~cm}$ of dried grass clippings on the floor of the cage. The other group was placed in an identical cage set-up within the quarantine laboratory under continuous light and constant temperature $\left(28 \pm 1{ }^{\circ} \mathrm{C}\right)$. A third group of 24 ovipositing adults, which emerged at a similar time and had been reared as larvae under constant light conditions in the laboratory, were placed outside in a small cage alongside the cage containing the first group. The cages were observed every few days for beetle activity and for the presence and numbers of eggs. 
A second test was conducted at Temple from 18 July to 18 September 2000. We used adults that emerged in outdoor field cages at Pueblo, Colorado in early July. Three large mesh bags $(25 \times 40 \mathrm{~cm})$, each containing 10 male and 10 female $D$. e. deserticola, were placed on saltcedar plants in an outdoor field cage under natural light and temperature conditions. A second identical group of 60 beetles was placed under a 16:8 light:dark cycle and held under relatively constant temperature conditions inside the quarantine laboratory (28.5 \pm $1.0^{\circ} \mathrm{C}$ ). Data on egg-laying and survival were collected twice a week. Occasionally, insects escaped or died early; these were replaced during the first 3 weeks of the study with an individual of the same sex, of similar age, and that was reared under similar conditions.

A third study to identify and characterize diapause was conducted in field cages in 2001. On 25 April, 85 1st, 2nd, and 3rd instar larvae and ca. 100 eggs of $D$. e . deserticola were placed on a single saltcedar tree inside a large field cage near Seymour, Texas. The larvae had been reared under light for $16 \mathrm{~h}$ in quarantine at the USDA-ARS laboratory at Albany, California. These insects successfully produced a second generation of adults and on 26 June 20 male and female pairs were placed in individual mesh bags on undamaged saltcedar branches outside of the field cage. Foliage inside the bags was periodically examined for eggs and live beetles during July and August. On 25 July, 10 of the pairs were moved to the quarantine laboratory at Temple and two females were dissected to examine the condition of their ovaries. The remaining eight pairs were maintained in individual mesh bags in quarantine under a light cycle of $16 \mathrm{~h}$ on potted plants of $T$. ramosissima and examined periodically for the presence of eggs. Daylength (sunrise to sunset) at the various field locations was determined by using the United States Naval Observatory's astronomical website (http://aa.usno.navy.mil), which calculates the potential maximum amount of daylight on a particular day for a specific location.

\subsection{Statistical analysis}

Data from the 1999 laboratory test that assessed the survival and reproduction of beetles reared on different Tamarix sp. and leaf ages were subjected to analysis of variance with the means separated by Fisher's Protected LSD Test (SAS Institute, 1990); proportional data were subjected to arc-sine square-root transformation and other data were subjected to the transformation $\ln (x+1)$. Data for total eggs and egg clusters laid during the diapause studies in 2000 were analyzed using the Independent-Samples $t$ test, SPSS software (Norusis, 1988). Data on survival and average eggs laid were nonparametric and were analyzed by ranks using the two-way Kruskal-Wallis test (SAS Institute, 1990).

\section{Results and discussion}

\subsection{Description and behavior of stages}

The following information on general appearance and behavior is from our studies and observations:

Egg. The eggs of D. e. deserticola are spherical to slightly ovoid, bright yellow when first laid but soon become light tan in coloration; eggs are $0.88 \pm 0.06$ by $0.77 \pm 0.02 \mathrm{~mm}($ mean $\pm \mathrm{SD})(n=10)$ and the chorion is sculptured. Eggs are laid in masses (Fig. 1A) and viability of eggs averaged $94.8 \pm 10.6 \%$ (range $62.5-100 \%$; $n=46$ egg masses). Duration was $5.0 \pm 0.0$ days at $28.3 \pm 0.7^{\circ} \mathrm{C}$ (14 masses, 168 eggs) during observations from 28 August to 7 September 1999 and $6.2 \pm 0.4$ days at $27.1 \pm 1.4{ }^{\circ} \mathrm{C}$ ( 26 masses, 225 eggs) in testing from 15 to 27 September 1999 in the laboratory (Table 1).

Larva. Measurements of head-capsule diameter indicated the presence of three larval instars (Table 1). This was confirmed in several laboratory observations by the recovery of the cast exuviae after each molt. The 1st instar is entirely black (Fig. 1B). The 2nd instars are black, with creamy-yellowish spots surrounding each spiracle, and the 3rd instars are grayish black, with thoracic shield creamy-yellow, alutaceous and two or more blackish spots laterally. The thorax and abdomen of 2 nd and 3rd instar larvae have a prominent creamy-yellowish ventrolateral spiracular stripe (Figs. 1B and C). Newly molted individuals of 2nd and 3rd instar larvae are yellowish but soon turn black. Full-grown 1st instars reach 1-2 mm long, 2nd instars ca. $4 \mathrm{~mm}$, and $3 \mathrm{rd}$ instars to ca. $9 \mathrm{~mm}$. Development of the larval stages in the laboratory at $24.1 \pm 1^{\circ} \mathrm{C}$ required an average of 21.9 days (Table 1 ).

All larval stadia feed on the foliage (small, scale-like leaves) of Tamarix spp. Larvae usually fed on the young terminal growth during the 1 st and 2nd instars; the more active 3rd instar larvae move to older growth if the terminal foliage had been mostly consumed. In addition, the larger larvae probably feed on the bark of the small twigs and larger first-year shoots (see discussion of adult feeding, below). When 3rd instars are full grown (after ca. 5 days) they cease feeding and crawl or drop from the plant. They then form a pupal cell from litter on the soil surface (Fig. 1D) and sometimes spin a few strands of silk around themselves before curling into a " $\mathrm{C}$ " shaped immobile prepupa for a few days before pupation. If leaf litter is unavailable, 3rd instars may enter loose soil to a depth of ca. $1 \mathrm{~cm}$ to form a pupal cell from soil (Fig. 1E).

Neonate larvae were the stage most sensitive to the quality of foliage for feeding and development, and they often died in our tests when placed on suboptimal testplant species (DeLoach et al., 2003). Most larvae surviving the 1st instar continued, with lesser mortality, to develop to mature 3rd instars. Survival from neonate to fully developed $3 \mathrm{rd}$ instars in the laboratory was $100 \%$ in 

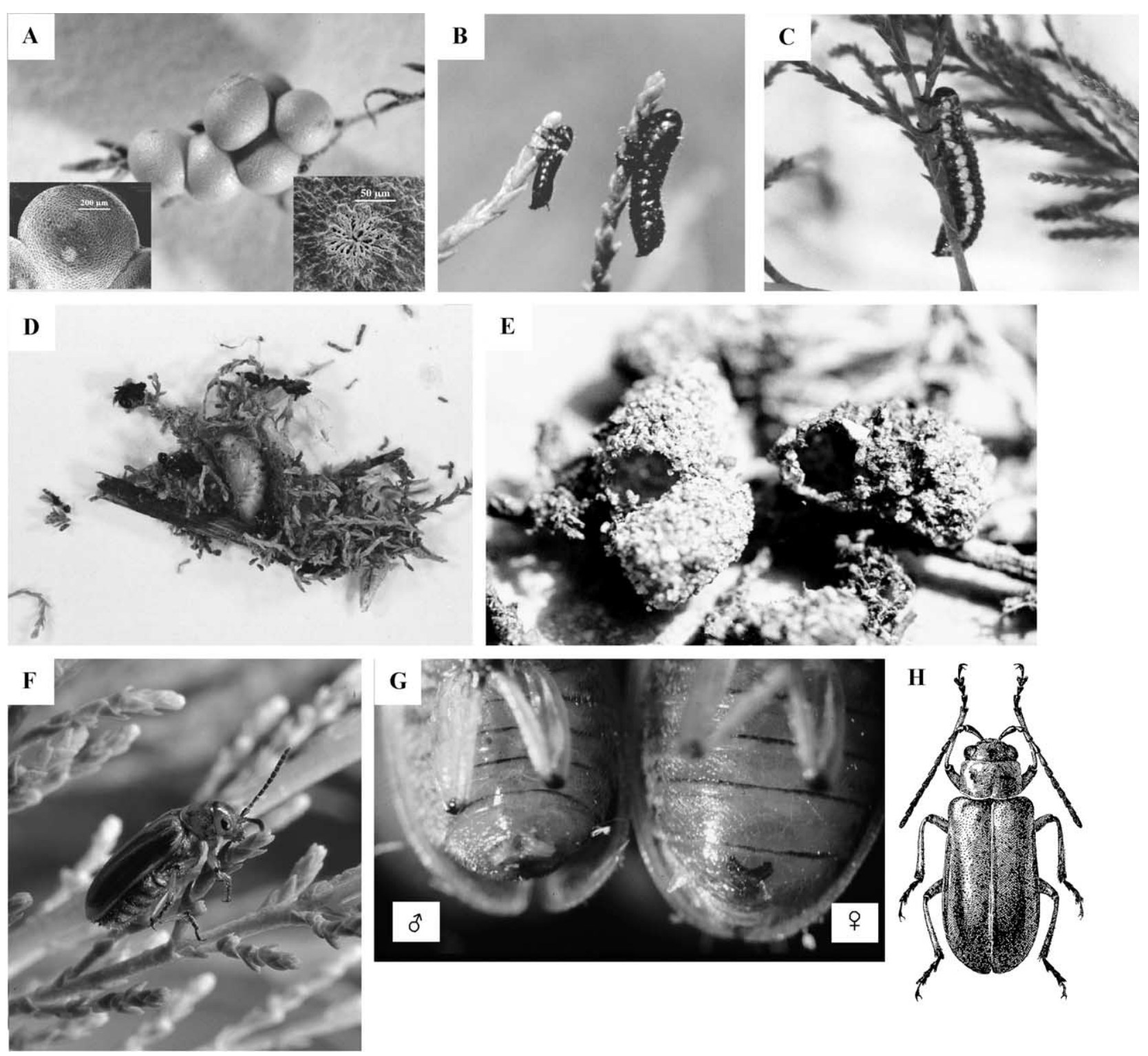

Fig. 1. Life stages of D. e. deserticola: (A) Egg mass on saltcedar foliage; left inset, SEM of egg cluster showing sculpturing of chorion; right inset detailing micropyle region; (B) 1st and 2nd instar larvae; (C) 3rd instar larva; (D) pupa in cell made from soil litter; (E) empty soil pupal cells; (F) adult; (G) male and female - note v-shaped notch in male and 3-lobed internal sternite in female. (H) Drawing of tamarisk leaf beetle, D. elongata (Brullé), from Ogloblin (1936).

some tests with larvae in mesh bags on growing terminals of the better accessions of potted T. ramosissima. Increased mortality in the laboratory during molting from the prepupal to the pupal stage seemed to be associated with poor plant quality during larval development; pupal mortality in outdoor mesh bags may have resulted from low humidity (observations at the Colorado field cages).

Pupa. Duration of the pupal stage in the laboratory was $7.1 \pm 0.8$ days (Table 1). Pupae averaged $6-7 \mathrm{~mm}$ in length and remained a uniform yellow throughout their developmental period (Fig. 1D). Pupae, unlike larvae, were extremely susceptible to injury from handling, which usually caused death or severe deformity. In our laboratory cultures, survival was greatest if we did not attempt to move them or to manipulate them after the early prepupal stage.

Adult. A generalized description of living adults from our observations is as follows (Fig. 1F): Females slightly larger than males; males averaged $5.6 \pm 0.2 \mathrm{~mm}$ in length and $2.2 \pm 0.1 \mathrm{~mm}$ in width $(n=10)$, females $5.9 \pm 0.2 \mathrm{~mm}$ in length and $2.4 \pm 0.1 \mathrm{~mm}$ in width $(n=10)$. General color yellowish with brown markings (tan to gray-brown with dark brown markings in dead specimens).

Head. Yellow to yellow-brown, shining, closely and coarsely punctate, with eyes black, frons with large rounded dark brown to black spot connected by narrow black sulcus to virtually impunctate occipital area, small dark spot on ventral portion of head. Occipital area 
Table 1

Life cycle, size, and description of D. e. deserticola ${ }^{\mathrm{a}}$

\begin{tabular}{|c|c|c|c|}
\hline \multirow[t]{2}{*}{ Stage } & \multicolumn{2}{|l|}{ Mean \pm SD $(n)$ (range) } & \multirow[t]{2}{*}{ Notes } \\
\hline & Duration in days & Head capsule width (mm) & \\
\hline \multirow[t]{2}{*}{ Egg } & $5.0 \pm 0.0(168)$ at $28.3 \pm 0.7^{\circ} \mathrm{C}$ & & $\begin{array}{l}\text { Tan, spherical; in masses of between } 1 \text { and } \\
25 \text { on foliage }\end{array}$ \\
\hline & $6.2 \pm 0.4(225)$ at $27.1 \pm 1.4^{\circ} \mathrm{C}$ & & \\
\hline \multicolumn{4}{|c|}{ 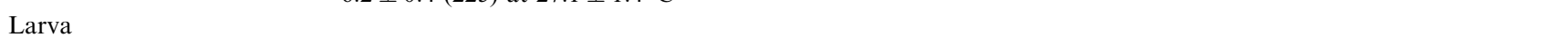 } \\
\hline 1st Instar & $4.9 \pm 1.0(52)(4-8)$ & $0.49 \pm 0.03(13)(0.45-0.53)$ & $1-2 \mathrm{~mm}$ long; black \\
\hline 2nd Instar & $4.8 \pm 1.0(39)(2-7)$ & $0.68 \pm 0.04(58)(0.58-0.75)$ & $\begin{array}{l}\text { To ca. } 4 \mathrm{~mm} \text { long; black with indistinct } \\
\text { yellowish stripe on each side of } \\
\text { abdomen }\end{array}$ \\
\hline 3rd Instar & & & $\begin{array}{l}\text { To ca. } 9 \mathrm{~mm} \text { long; gray-black with a } \\
\text { distinct longitudinal yellow stripe on each } \\
\text { side of abdomen }\end{array}$ \\
\hline Active & $7.4 \pm 1.7(28)(3-11)$ & $1.01 \pm 0.05(50)(0.88-1.10)$ & \\
\hline Prepupa & $4.8 \pm 1.5(18)(3-8)$ & & $\begin{array}{l}\text { Drops to ground, may burrow and form } \\
\text { pupal cell in soil or leaf litter; adopts a } \\
\text { C-shaped position }\end{array}$ \\
\hline Total larval & $22.6 \pm 2.7(11)(20-29)$ & & \\
\hline Pupa & $7.1 \pm 0.8(13)(5-8)$ & & 6-7 mm long, yellow \\
\hline Adult & & & $\begin{array}{l}\text { Males averaged } 5.6 \pm 0.2 \mathrm{~mm} \text { long, by } \\
2.2 \pm 0.1 \mathrm{~mm} \text { wide }(n=10) . \text { Females } \\
5.9 \pm 0.2 \mathrm{~mm} \text { long, by } 2.4 \pm 0.1 \mathrm{~mm} \text { wide } \\
(n=10)\end{array}$ \\
\hline Adult preoviposition & $3.9 \pm 1.1(17)(3-7)$ & & \\
\hline Adult oviposition & $12.0 \pm 6.4(15)(4-26)$ & & \\
\hline Adult total longevity & $18.8 \pm 6.7(14)(12-32)$ & & \\
\hline $\begin{array}{l}\text { Total life cycle (to peak } \\
\text { oviposition of female) }\end{array}$ & $37-41$ days & & \\
\hline
\end{tabular}

broadly banded with dark brown to black, fading to yellow behind eyes. Anterior margin of labrum, mandibles, and apical segments of labial and maxillary palpae brown to black. Antennae with basal three segments yellowish marked anteriorly with brown; distal segments 4-11, brown to black.

Pronotum. Broader than long, yellow, shining, with three discal brown to black spots (one small median and two larger and darker lateral spots, lateral spots bordered anteriorly by two medio-lateral depressions on disc), median spot sometimes evanescing (two shallow disconnected depressions along midline with dark spot in basal one); occasionally all spots evanescing. Laterally with coarse close punctures, moderate widely scattered punctures on disc.

Scutellum. Broadly triangular and apically rounded, pale yellowish.

Elytra. Yellow to yellow-brown with two dark brown to black discal stripes on each elytron. Stripes generally broad and joined posteriorly or evanescing basally or evanescing both basally and apically and not joined; subsutural reaches basal one-sixth to two-fifths, mediolateral reaching humeral callus which is marked with brown, or broken basally and not joined to humeral callus. Elytral surface appearing glabrous but covered with widely scattered short pale setae, more evident along lateral and apical margins; coarsely, closely irregularly punctate on surface. Submarginal and discal carinae moderate to strong. Lateral margin strongly explanate and carinate, less so apically.

Legs. Pale yellow except dark brown to black at apices of femora, apices of tibiae and all tarsae; also, a dark spot usually present on middle posterior of anterior femora and on middle anterior of middle femora.

Abdomen. Last visible abdominal tergites broadly marked with dark brown or black with anterior and posterior margins pale yellow. Pygidium dark brown to black with elongate subapical marginal pale spots. Sternites pale yellow, with darkened lateral areas of metasternum and dark brown to black lateral areas on abdominal segments, paler in some specimens or nearly dark in others. Undersurface clothed with longer depressed pale pubescence not obscuring surface. Last visible abdominal sternite in male truncated and deeply notched with "V"; in female, broadly rounded, with dark brown sclerotized internal 8th sternite (shaped like very broad "Y") usually clearly visible through the integument (Fig. 1G).

Adults, like larvae, feed on the foliage of saltcedar. Adults in laboratory cages on potted plants, or in field 
Table 2

Time required for development of $D$. e. deserticola in four outdoor studies under variable conditions and at one constant laboratory temperature ${ }^{\mathrm{a}}$

\begin{tabular}{|c|c|c|c|c|c|c|c|}
\hline \multirow[t]{2}{*}{ Study location } & \multirow{2}{*}{$\begin{array}{l}\text { Ave. temp. } \\
\left({ }^{\circ} \mathrm{C}\right)\end{array}$} & \multicolumn{6}{|c|}{ Days of development (mean $\pm \mathrm{SD} ;(n))$} \\
\hline & & 1st instar & 2nd instar & 3rd instar & Prepupa & Pupa & Total \\
\hline Temple, Aug.'99 & $30.4 \pm 5.3$ & $\begin{array}{l}3.7 \pm 0.8 \mathrm{a} \\
(25)\end{array}$ & $\begin{array}{l}3.0 \pm 0.6 \mathrm{ab} \\
(25)\end{array}$ & $\begin{array}{l}3.0 \pm 0.7 \mathrm{a} \\
(23)\end{array}$ & $\begin{array}{l}3.1 \pm 0.7 \mathrm{a} \\
(23)\end{array}$ & $\begin{array}{l}5.3 \pm 0.6 \mathrm{a} \\
(22)\end{array}$ & $\begin{array}{l}18.1 \pm 0.9 \mathrm{a} \\
(22)\end{array}$ \\
\hline Temple, Sept.'99 & $26.7 \pm 6.1$ & $\begin{array}{l}3.5 \pm 0.3 \mathrm{a} \\
(25)\end{array}$ & $\begin{array}{l}3.3 \pm 0.5 \mathrm{~b} \\
(25)\end{array}$ & $\begin{array}{l}4.0 \pm 0.9 \mathrm{~b} \\
(25)\end{array}$ & $\begin{array}{l}4.6 \pm 1.3 b \\
(20)\end{array}$ & $\begin{array}{l}7.3 \pm 0.7 b c \\
(15)\end{array}$ & $\begin{array}{l}22.3 \pm 1.4 b \\
(15)\end{array}$ \\
\hline Dallas, June’00 & $26.4 \pm 5.5$ & $\begin{array}{l}4.5 \pm 0.8 \mathrm{c} \\
(29)\end{array}$ & $\begin{array}{l}2.9 \pm 0.8 \mathrm{a} \\
(26)\end{array}$ & $\begin{array}{l}3.9 \pm 1.9 \mathrm{~b} \\
(24)\end{array}$ & $\begin{array}{l}4.9 \pm 1.1 \mathrm{~b} \\
(23)\end{array}$ & $\begin{array}{l}8.0 \pm 1.3 \mathrm{~d} \\
(22)\end{array}$ & $\begin{array}{l}24.1 \pm 2.3 \mathrm{c} \\
(22)\end{array}$ \\
\hline Dallas, Oct.'99 & $24.6 \pm 4.6$ & $\begin{array}{l}4.1 \pm 0.5 \mathrm{~b} \\
(29)\end{array}$ & $\begin{array}{l}3.8 \pm 0.5 \mathrm{c} \\
(28)\end{array}$ & $\begin{array}{l}3.6 \pm 0.8 \mathrm{ab} \\
(26)\end{array}$ & $\begin{array}{l}6.0 \pm 1.7 \mathrm{c} \\
(22)\end{array}$ & $\begin{array}{l}7.8 \pm 0.8 \mathrm{~cd} \\
(22)\end{array}$ & $\begin{array}{l}25.3 \pm 1.5 \mathrm{~d} \\
(22)\end{array}$ \\
\hline Temple, Lab.'92 & $24.1 \pm 2.0$ & $\begin{array}{l}5.7 \pm 0.8 \mathrm{~d} \\
(11)\end{array}$ & $\begin{array}{l}4.7 \pm 1.4 \mathrm{~d} \\
(11)\end{array}$ & $\begin{array}{l}7.2 \pm 2.1 \mathrm{c} \\
(11)\end{array}$ & $\begin{array}{l}4.9 \pm 1.5 \mathrm{~b} \\
(11)\end{array}$ & $\begin{array}{l}7.0 \pm 0.8 \mathrm{~b} \\
(11)\end{array}$ & $\begin{array}{l}29.5 \pm 2.5 \mathrm{e} \\
\text { (11) }\end{array}$ \\
\hline
\end{tabular}

${ }^{a}$ Means within the same column followed by the same letter are not significantly different $(P<0.05$, LSD 1-way ANOVA; Norusis, 1988).

cages on plants $2-3 \mathrm{~m}$ tall, appeared to feed first on younger foliage, but later fed also on older foliage. They fed on the leaves but sometimes also fed on the epidermis of twigs and first-year shoots, causing the foliage on the terminal part of the twig to desiccate and die. A line drawing of the adult is provided in Fig. $1 \mathrm{H}$.

Females glue eggs to the foliage singly or in masses ranging from 2 to 20 , but typically average $3.1 \pm 1.7$ eggs per mass (range 1-13) (Fig. 1A), based on 432 egg masses laid by the 30 females held in mesh bags outdoors (part of the diapause study). These same females laid twice as many eggs per mass on the mesh bags as on the foliage $(6.7 \pm 3.8$ eggs, $n=142$ masses; $P=0.0001$, independent samples $t$ test). In the field in Kazakhstan, egg-mass size on saltcedar foliage averaged $2.6 \pm 1.4$ eggs per mass ( $n=59$ masses) (Mityaev and Jashenko, 1998), which was similar to our observations at Temple.

\subsection{Degree-days and development time}

Developmental rate of individual larvae in mesh bags on plants growing in outdoor cages was assessed at Temple and Dallas, and of larvae on excised foliage within vials in the laboratory at Temple. Mean time for development of each of the three larval instars took between 2.9 and 7.2 days. Each larval instar developed more rapidly outside on living foliage than did individuals reared in the laboratory on excised twigs and constant temperature conditions (Table 2). Prepupa averaged from 3.1 to 6.0 days to develop among the tests while the pupal stage required 5.3-8.0 days. Total time for development from egg-hatch to adult eclosion ranged from 18.1 days at $30.4{ }^{\circ} \mathrm{C}$ in the outdoor test during August to 29.5 days at the relatively constant $24.1^{\circ} \mathrm{C}$ in the laboratory. Temperatures in June, August, and September were higher outside than in the laboratory, which would account for the shorter development time outdoors. Although the overall average temperature during October in Dallas was similar to the laboratory average, this outdoor period yielded more heat units and explains the more rapid development of these insects. It also suggests that the use of excised foliage does not retard larval development to any great extent. Beetles reared at each higher average temperature had significantly different and progressively shorter development times based on the total number of days from egg hatch to adult emergence (Table 2, Fig. 2).

Degree-days for the development of each stage were calculated based on the mean development times of the five data sets in Table 2. Development time from egg hatch to adult eclosion was reduced with each higher average daily temperature (open circles, Fig. 2). A regression of development rate (1/days) on temperature was described by the equation $y=0.0031 x-0.0389$ with an $R^{2}$ value of 0.95 (dark diamonds, Fig. 2). Solving for $x$ in the equation gave a developmental threshold temperature of $12.5^{\circ} \mathrm{C}$. We recognize that the linear relationship this $R^{2}$ value suggests is due to the limited range of temperatures available for our experiment.

The mean degree-day accumulations $( \pm \mathrm{SD})$ for completion of each life stage were: first instar $62.6 \pm$ 12.3; second instar $52.7 \pm 12.5$; third instar $57.1 \pm 18.9$; prepupa $61.8 \pm 18.0$; pupa $91.3 \pm 13.0(n=119,114$, 107, 97, and 92, respectively). An average total accumulation of $325.8 \pm 22.9 \quad(n=92)$ degree-days were required for development from egg hatch to adult eclosion. This value is similar to the 357.4 degree-days $\left(K=11.1^{\circ} \mathrm{C}\right)$ required for the development of the immature stages of Xanthogaleruca luteola (Müller), the elm leaf beetle, a prominent pest insect introduced from the Old World (Luck and Scriven, 1976; King et al., 1985), which is of a similar size and life history as Diorhabda.

The use of $12.5^{\circ} \mathrm{C}$ in these studies as the threshold temperature for development is only valid over the range of temperatures considered. At higher or lower temperatures, or under constant temperatures and con- 


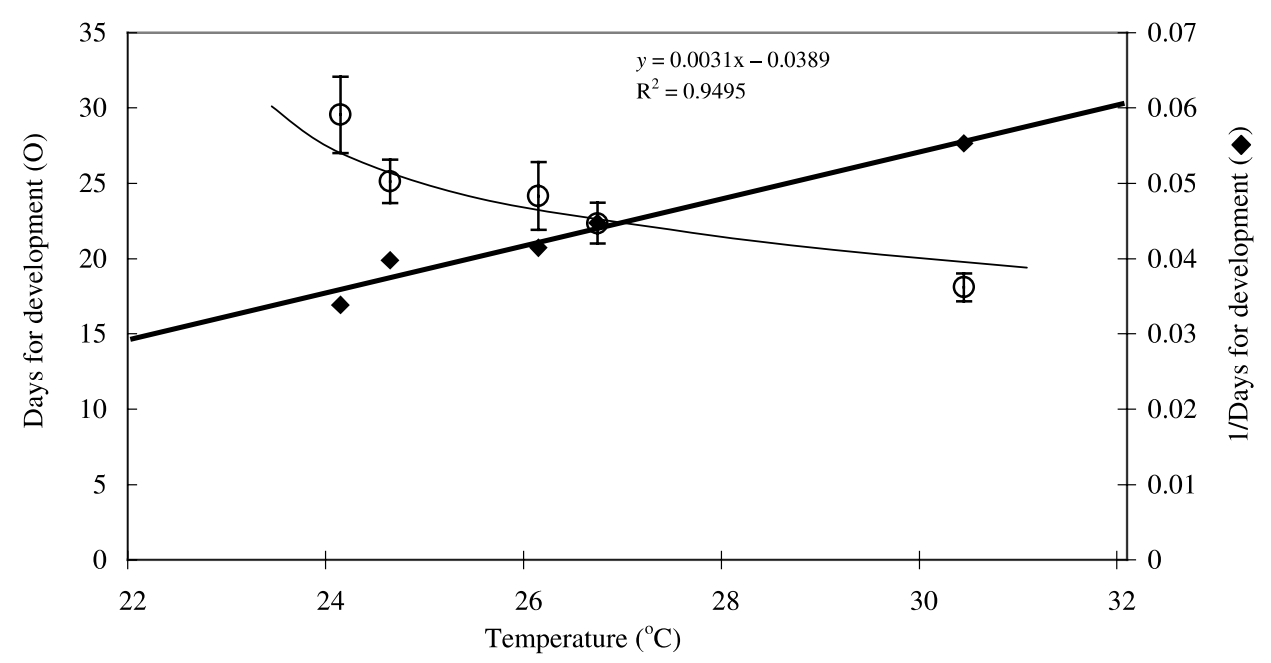

Fig. 2. Days $(\mathrm{O})$ and rate $(\bullet)$ of development from egg eclosion to adult emergence of $D$. e. deserticola in outdoor field cages and variable temperatures. Means $\pm \mathrm{SD}$ values for five studies (From data in Table 2).

trolled conditions, this baseline may be different. Additional studies are needed to refine and characterize the upper and lower developmental limits for this insect.

The developmental degree-day estimates obtained through these studies were sufficient to predict the emergence of the 1 st generation $D$. e. deserticola in the field at three research sites in the United States (Table 3). Degree-day accumulations for the 2nd generation, which develops during the warmer period of the summer, were greater than predicted values, indicating slower than expected development perhaps due to periods of unfavorably high temperature. Once an upper temperature development limit for this insect is determined, we expect a more accurate prediction of development time during high temperature conditions. Degree-day accumulations during the development of the three Diorhabda generations observed at the Fukang, China location was consistent with the predicted value (Table 3 ).

\subsection{Survival, developmental, and reproductive parameters on Tamarix spp.}

Studies of larval survival and development of $D$. $e$. deserticola on four Tamarix species, two accessions of T. ramosissima, and different leaf ages provided additional biological information on this insect's survival, reproduction, and longevity (Table 4). Survival from egg hatch to adult was $90.8 \%$ on young foliage of $T$. ramosissima from Lovelock, Nevada, which is significantly greater than on old foliage of this accession and the other three Tamarix species. Survival on T. ramosissima from Lovell, Wyoming was $82.6 \%$ while survival on $T$. aphylla, T. parviflora, and T. canariensis ranged from 70.8 to $53.1 \%$. However, DeLoach et al. (2003) reported survival ranges as high as $83.3 \%$ on some accessions of all three of these test plants. Young foliage of the two $T$. ramosissima accessions was similar in its ability to sustain larval development. Development from neonate larvae to adult eclosion required from 23.0 to 25.8 days in this study and was significantly more rapid on both old and young foliage of the Lovelock accession of $T$. ramosissima as compared to the other test plants. The slowest development time was on $T$. canariensis.

Reproductive parameters differed between adult females fed excised foliage of the different Tamarix species, accessions, or leaf ages on which they had been reared as larvae (Table 4). Adults fed on young foliage of the $T$. ramosissima accession from Lovell had the shortest preoviposition period, oviposited longer, lived longer, and laid the most eggs (194.5) during their life. Adults from the three $T$. ramosissima accessions required a preoviposition period of from 3.9 to 4.4 days, significantly shorter than the 5.1-5.4 days needed by adults reared from larvae on and feeding as adults on the other Tamarix species. The mean period of oviposition varied from 12.0 to 6.2 days among individuals and mean adult longevity ranged from 12.5 to 18.8 days. Average eggs laid per female was greatest on young foliage of $T$. ramosissima and $T$. canariensis, somewhat less on $T$. parviflora, and least on old foliage of T. ramosissima and on T. aphylla. Poor larval survival on a test plant did not result in any obvious impairment in female reproduction, suggesting that females are more flexible than larvae in being able to derive sufficient nutrition from plants, regardless of the Tamarix species or leaf quality available.

From these data on larval survival and female reproductive capacity (Table 4), we calculated population growth statistics for $D$. e. deserticola for each of the test plants (Table 5). The number of females produced by an average female during one generation in a pop- 
Table 3

Comparison of predicted degree-days for D. e. deserticola to phenology noted in the field

\begin{tabular}{|c|c|c|c|c|}
\hline Observed life stage in the field & Dates & $\begin{array}{l}\text { Accumulated } \\
\text { degree-days }\end{array}$ & $\begin{array}{l}\text { Predicted } \\
\text { degree-days }^{\mathrm{a}}\end{array}$ & Field notes \\
\hline \multicolumn{5}{|l|}{ Colorado'99-1st generation } \\
\hline Egg-hatch & $5 / 26-6 / 7$ & 87.0 & 84.8 & No larvae on $6 / 2 ; 1$ st instars $6 / 9$ \\
\hline 1st instar-adult & $6 / 8-7 / 8$ & 310.8 & $325.4 \pm 22.9$ & $\begin{array}{l}\text { 1st Tenerals on } 7 / 8 \text { (estimate peak adult } \\
\text { emergence } 7 / 14 \text { ) }\end{array}$ \\
\hline \multicolumn{5}{|l|}{ 2nd Generation } \\
\hline Egg_hatch & $7 / 19-7 / 26$ & 87.1 & 84.8 & (5 Days for preoviposition) \\
\hline 1 st -3 rd instar & $7 / 27-8 / 24$ & 319.2 & $172.3 \pm 25.5$ & Mostly 3 rd instars on $8 / 24$ \\
\hline Pupation-adult & $8 / 27-9 / 8$ & 165.5 & $153.4 \pm 19.8$ & Many adults on $9 / 8$ \\
\hline \multicolumn{5}{|l|}{ Colorado'00-1st generation } \\
\hline Egg_adult & $5 / 15-7 / 4$ & 444.7 & $411 \pm 30$ & $\begin{array}{l}\text { Many eggs noted on } 5 / 15 \text {; next obser- } \\
\text { vation on } 7 / 6 \text {, many tenerals }\end{array}$ \\
\hline \multicolumn{5}{|l|}{ Colorado'01-1st generation } \\
\hline Egg_adult & $5 / 10-7 / 3$ & 421.3 & $411 \pm 30$ & $\begin{array}{l}\text { Eggs observed on } 5 / 10 \text {; teneral adults } \\
\text { observed on } 7 / 3\end{array}$ \\
\hline \multicolumn{5}{|l|}{ 2nd Generation } \\
\hline Egg-adult & $7 / 12-8 / 19$ & 493.5 & $411 \pm 30$ & $\begin{array}{l}\text { First eggs observed on } 7 / 9 \text {; many adults } \\
\text { seen from } 8 / 19 \text { to } 8 / 28\end{array}$ \\
\hline \multicolumn{5}{|l|}{ Fukang, China'97-1st generation } \\
\hline Egg_adult & $4 / 21-6 / 4$ & 424.8 & $411 \pm 30$ & Eggs seen late April, adults early June \\
\hline 2nd Generation & & & & (5 Days preoviposition) \\
\hline Egg_adult & $6 / 9-7 / 10$ & 425.0 & $411 \pm 30$ & Eggs seen mid-June, adults mid-July \\
\hline 3rd Generation & & & & (5 Days preoviposition) \\
\hline Egg_adult & $7 / 15-8 / 17$ & 426.9 & $411 \pm 30$ & Eggs seen mid-July, adults mid-Aug. \\
\hline \multicolumn{5}{|l|}{ Temple'99-1st generation } \\
\hline Egg - adult & $5 / 25-6 / 24$ & 404.6 & $411 \pm 30$ & $\begin{array}{l}\text { Eggs obtained late May, adults late } \\
\text { June }\end{array}$ \\
\hline \multicolumn{5}{|l|}{ 2nd Generation } \\
\hline Egg_adult & $7 / 1-8 / 3$ & 517.5 & $411 \pm 30$ & Eggs seen early July, adults 3 August \\
\hline \multicolumn{5}{|l|}{ Wyoming'00-1st generation } \\
\hline Egg_adult & $6 / 2-7 / 13$ & 376.2 & $411 \pm 30$ & Eggs seen on $6 / 2$ \\
\hline 2nd Generation & & & & (5 Days preoviposition) \\
\hline Egg_adult & $\sim 7 / 19-9 / 8$ & 569.1 & $411 \pm 30$ & Many adults on $9 / 8$ \\
\hline
\end{tabular}

${ }^{a}$ Egg degree-days (84.8) were estimated from egg hatch data listed in Table 1; the predicted degree-day value of $411 \pm 30$ for egg to adult development was obtained by adding the value of 325.4 calculated in this paper to the estimated degree-days needed for egg hatch.

ulation $\left(R_{0}\right)$ on young foliage of $T$. ramosissima from Lovell was 88.2 , significantly higher than on any other species and accession tested. Mean generation time $(T)$, or the mean period over which progeny are produced, was not significantly different between test plants and varied from 36.8 to 41.3 days. The innate capacity for increase $\left(r_{\mathrm{m}}\right)$, or the rate of increase of a population at a stable age-distribution and growing under optimal conditions, varied from 0.088 to 0.112 and was significantly higher on young $T$. ramosissima from Lovell as compared to old $T$. ramosissima and the other three Tamarix species. The number of days required for a population to double in size (DT) ranged from 6.2 to
6.4 days on accessions of young foliage of $T$. ramosissima to 7.5-8.0 days on the other three Tamarix species and old foliage of $T$. ramosissima (Table 5). We conclude that young $T$. ramosissima foliage is most suited for a rapid population growth of $D$. e. deserticola, but all four Tamarix spp. appear to be suitable hosts for sustaining populations of this beetle in North America.

\subsection{Seasonal history}

Seasonal occurrence of generations. Daylength, latitude, and population milestones of D. e. deserticola from 
Table 4

Development and reproductive parameters of D. e. deserticola reared as larvae and adults on the same Tamarix species and accessions ${ }^{\mathrm{a}}$

\begin{tabular}{|c|c|c|c|c|c|c|}
\hline \multirow[t]{2}{*}{$\begin{array}{l}\text { Tamarix species/ } \\
\text { accession, leaf age }\end{array}$} & \multicolumn{2}{|c|}{$\begin{array}{l}\text { Larval survival and development } \\
\text { Mean } \pm \mathrm{SD}(n) \text { (range) }\end{array}$} & \multicolumn{4}{|c|}{ Female reproduction and longevity Mean $\pm \mathrm{SD}(n)(\text { range })^{\mathrm{c}}$} \\
\hline & $\begin{array}{l}\% \text { Survival } \\
\text { neonate larva to } \\
\text { adult }^{\mathrm{b}}\end{array}$ & $\begin{array}{l}\text { Days to } \\
\text { development } \\
\text { neonates to adult }\end{array}$ & $\begin{array}{l}\text { Preoviposition } \\
\text { period (days) }\end{array}$ & $\begin{array}{l}\text { Oviposition } \\
\text { period (days) }\end{array}$ & $\begin{array}{l}\text { Total adult } \\
\text { longevity (days) }\end{array}$ & $\begin{array}{l}\text { Average eggs } \\
\text { per female }\end{array}$ \\
\hline $\begin{array}{l}\text { T. ramosissima, } \\
\text { Lovell WY, } \\
\text { Young }\end{array}$ & $\begin{array}{l}82.6 \pm 8.8(3) a b \\
(0.75-0.93)\end{array}$ & $\begin{array}{l}24.5 \pm 1.9(101) b \\
(22-33)\end{array}$ & $\begin{array}{l}3.9 \pm 1.1(17) b \\
(3-7)\end{array}$ & $\begin{array}{l}12.0 \pm 6.4(15) \mathrm{a} \\
(4-26)\end{array}$ & $\begin{array}{l}18.8 \pm 6.7(14) \mathrm{a} \\
(12-32)\end{array}$ & $\begin{array}{l}194.5 \pm 132.6(15) \mathrm{a} \\
(78-550)\end{array}$ \\
\hline $\begin{array}{l}\text { T. ramosissima, } \\
\text { Lovelock NV, } \\
\text { Young }\end{array}$ & $\begin{array}{l}90.8 \pm 3.8(3) \mathrm{a} \\
(0.88-0.95)\end{array}$ & $\begin{array}{l}23.0 \pm 1.5(109) \mathrm{c} \\
(21-32)\end{array}$ & $\begin{array}{l}4.4 \pm 1.3(17) b \\
(2-8)\end{array}$ & $\begin{array}{l}9.5 \pm 5.5(17) a b c \\
(1-23)\end{array}$ & $\begin{array}{l}15.5 \pm 5.3(17) \text { abcd } \\
(9-30)\end{array}$ & $\begin{array}{l}127.9 \pm 74.7(17) \mathrm{ab} \\
(31-270)\end{array}$ \\
\hline $\begin{array}{l}\text { T. ramosissima, } \\
\text { Lovelock NV, } \\
\text { Old }\end{array}$ & $\begin{array}{l}64.4 \pm 5.1(3) \mathrm{cd} \\
(0.60-0.70)\end{array}$ & $\begin{array}{l}23.5 \pm 1.5(58) \mathrm{c} \\
(22-32)\end{array}$ & $\begin{array}{l}4.2 \pm 0.8(11) b \\
(3-5)\end{array}$ & $\begin{array}{l}7.2 \pm 2.5(11) b c \\
(4-11)\end{array}$ & $\begin{array}{l}12.5 \pm 3.1(10) \mathrm{d} \\
(7-17)\end{array}$ & $\begin{array}{l}94.7 \pm 50.3(11) b c \\
(29-199)\end{array}$ \\
\hline $\begin{array}{l}\text { T. parviflora, } \\
\text { Lovelock NV, } \\
\text { Young }\end{array}$ & $\begin{array}{l}70.5 \pm 4.8(3) \mathrm{bc} \\
(0.65-0.74)\end{array}$ & $\begin{array}{l}24.7 \pm 1.8(92) b \\
(21-31)\end{array}$ & $\begin{array}{l}5.1 \pm 1.2(27) \mathrm{a} \\
(3-8)\end{array}$ & $\begin{array}{l}10.2 \pm 5.4(27) a b \\
(2-28)\end{array}$ & $\begin{array}{l}17.6 \pm 6.0(26) a b \\
(8-33)\end{array}$ & $\begin{array}{l}123.2 \pm 73.8(27) b \\
(21-324)\end{array}$ \\
\hline $\begin{array}{l}\text { T. canariensis, } \\
\text { Galveston TX, } \\
\text { Young }\end{array}$ & $\begin{array}{l}53.1 \pm 10.4(3) \mathrm{d} \\
(0.47-0.65)\end{array}$ & $\begin{array}{l}25.8 \pm 2.5(59) \mathrm{a} \\
(22-31)\end{array}$ & $\begin{array}{l}5.3 \pm 1.3(11) \mathrm{a} \\
(4-8)\end{array}$ & $\begin{array}{l}11.0 \pm 9.1(11) a b \\
(3-35)\end{array}$ & $\begin{array}{l}18.5 \pm 9.1(11) a b c \\
(9-42)\end{array}$ & $\begin{array}{l}146.8 \pm 120.7(11) a b \\
(25-427)\end{array}$ \\
\hline $\begin{array}{l}\text { T. aphylla, } \\
\text { Uvalde/Encino } \\
\text { TX, Young }\end{array}$ & $\begin{array}{l}70.8 \pm 14.6(3) b c \\
(0.60-0.88)\end{array}$ & $\begin{array}{l}24.6 \pm 2.0(84) b \\
(21-32)\end{array}$ & $\begin{array}{l}5.4 \pm 1.3(19) \mathrm{a} \\
(4-9)\end{array}$ & $\begin{array}{l}6.2 \pm 3.2(19) \mathrm{c} \\
(2-16)\end{array}$ & $\begin{array}{l}13.7 \pm 2.9(19) \mathrm{cd} \\
(10-21)\end{array}$ & $\begin{array}{l}81.4 \pm 64.6(19) \mathrm{c} \\
(17-294)\end{array}$ \\
\hline
\end{tabular}

${ }^{a}$ Means within the same column followed with the same letter are not significantly different $(P<0.05$, Fisher's Protected LSD Test; SAS Institute, 1990). Prior to analysis, proportional survival data were subjected to the arc-sine square-root transformation and development time and female reproduction and longevity data were subjected to the transformation $\ln (x+1)$. Temperature conditions in the quarantine laboratory at this time averaged $28.6 \pm 0.8^{\circ} \mathrm{C}$

${ }^{\mathrm{b}}$ For analysis, larvae were placed in 3 cohorts of 30-46 larvae, each cohort reared on separate potted plants of that accession.

${ }^{\mathrm{c}}$ Number of females is not the same for all characteristics due to the loss or escape of some females.

Table 5

Population growth statistics for D. e. deserticola females reared on Tamarix species and accessions ${ }^{\mathrm{a}}$

\begin{tabular}{|c|c|c|c|c|}
\hline \multirow{2}{*}{$\begin{array}{l}\text { Tamarix species, females per } \\
\text { group/Accession, leaf age }\end{array}$} & \multicolumn{4}{|c|}{ Mean \pm SD (range) } \\
\hline & $\begin{array}{l}\text { Net reproductive } \\
\text { rate }\left(R_{\mathrm{o}}\right)\end{array}$ & $\begin{array}{l}\text { Mean generation time } \\
\text { in days }(T)^{\mathrm{b}}\end{array}$ & $\begin{array}{l}\text { Innate capacity for } \\
\text { increase }\left(r_{\mathrm{m}}\right)\end{array}$ & $\begin{array}{l}\text { Population doubling } \\
\text { time in days }(D T)\end{array}$ \\
\hline $\begin{array}{l}\text { T. ramosissima, } n=6,7 \\
\text { Lovell, WY, Young }\end{array}$ & $\begin{array}{l}88.2 \pm 24.0 \mathrm{a} \\
(71.3-105.2)\end{array}$ & $\begin{array}{l}39.9 \pm 0.2 \mathrm{a} \\
(39.7-40.0)\end{array}$ & $\begin{array}{l}0.112 \pm 0.006 \mathrm{a} \\
(0.107-0.116)\end{array}$ & $\begin{array}{l}6.2 \pm 0.4 \mathrm{c} \\
(6.0-6.5)\end{array}$ \\
\hline $\begin{array}{l}\text { T. ramosissima, } n=5,8,4 \\
\text { Lovelock, NV, Young }\end{array}$ & $\begin{array}{l}55.9 \pm 7.0 \mathrm{~b} \\
(48.0-61.2)\end{array}$ & $\begin{array}{l}37.1 \pm 7.0 \mathrm{a} \\
(36.2-38.5)\end{array}$ & $\begin{array}{l}0.108 \pm 0.007 \mathrm{ab} \\
(0.101-0.113)\end{array}$ & $\begin{array}{l}6.4 \pm 0.4 b c \\
(6.2-6.9)\end{array}$ \\
\hline $\begin{array}{l}\text { T. ramosissima, } n=3,4,3 \\
\text { Lovelock, NV, Old }\end{array}$ & $\begin{array}{l}29.9 \pm 6.2 \mathrm{c} \\
(24.4-36.6)\end{array}$ & $\begin{array}{l}36.8 \pm 0.6 \mathrm{a} \\
(36.1-37.2)\end{array}$ & $\begin{array}{l}0.092 \pm 0.004 \mathrm{bc} \\
(0.089-0.097)\end{array}$ & $\begin{array}{l}7.5 \pm 0.3 \mathrm{ab} \\
(7.2-7.8)\end{array}$ \\
\hline $\begin{array}{l}\text { T. parviflora, } n=7,9,10 \\
\text { Lovelock, NV, Young }\end{array}$ & $\begin{array}{l}43.4 \pm 5.1 \mathrm{bc} \\
(39.6-49.2)\end{array}$ & $\begin{array}{l}40.1 \pm 5.1 \mathrm{a} \\
(39.3-41.9)\end{array}$ & $\begin{array}{l}0.092 \pm 0.003 \mathrm{bc} \\
(0.088-0.095)\end{array}$ & $\begin{array}{l}7.6 \pm 0.3 \mathrm{ab} \\
(7.3-7.9)\end{array}$ \\
\hline $\begin{array}{l}\text { T. canariensis, } n=4,4,3 \\
\text { Galveston, TX, Young }\end{array}$ & $\begin{array}{l}38.9 \pm 13.2 \mathrm{bc} \\
(25.6-52.0)\end{array}$ & $\begin{array}{l}41.3 \pm 4.9 \mathrm{a} \\
(36.2-46.0)\end{array}$ & $\begin{array}{l}0.088 \pm 0.008 \mathrm{c} \\
(0.080-0.095)\end{array}$ & $\begin{array}{l}7.9 \pm 0.7 \mathrm{a} \\
(7.3-8.7)\end{array}$ \\
\hline $\begin{array}{l}\text { T. aphylla, } n=11,7 \\
\text { Uvalde/Encino TX, Young }\end{array}$ & $\begin{array}{l}34.8 \pm 24.6 \mathrm{bc} \\
(17.4-52.2)\end{array}$ & $\begin{array}{l}38.4 \pm 1.8 \mathrm{a} \\
(37.1-39.6)\end{array}$ & $\begin{array}{l}0.088 \pm 0.016 \mathrm{c} \\
(0.077-0.100)\end{array}$ & $\begin{array}{l}8.0 \pm 1.5 \mathrm{a} \\
(6.9-9.0)\end{array}$ \\
\hline
\end{tabular}

${ }^{a}$ Adults reared on potted treatment plants in laboratory $\left(27.9 \pm 1.4{ }^{\circ} \mathrm{C}, \mathrm{LD} 24: 0,60 \% \mathrm{Rh}\right)$ and, upon emergence, male/female pairs of the same age were held in yogurt cups and fed small bouquets of treatment plants. Only females laying fertile eggs were used for reproductive data. Means within the same column followed with the same letter are not significantly different $(P<0.05$, Fisher's Protected LSD Test; SAS Institute, 1990).

${ }^{\mathrm{b}}$ Calculation was based on a value of 6 days for egg hatch.

four United States research locations and the research and collection site near Fukang, China are given in Table 6. D. e. deserticola failed to overwinter in Texas and populations were initiated each spring from other locations and laboratories. However, the beetle completed a maximum of two generations and successfully overwin- 
Table 6

Seasonality of $D$. e. deserticola in relation to daylength (H:Min) and reproductive diapause ${ }^{\text {a }}$

\begin{tabular}{|c|c|c|c|c|c|c|}
\hline Date & $\begin{array}{l}\text { Fukang, China } \\
44.17^{\circ} \mathrm{N} ; 87.98^{\circ} \mathrm{E} \\
\text { Elev. } 552 \mathrm{~m} \\
1997\end{array}$ & $\begin{array}{l}\text { Lovell, WY } \\
44.84^{\circ} \mathrm{N} ; 108.39^{\circ} \mathrm{W} \\
\text { Elev. } 1170 \mathrm{~m} \\
2000\end{array}$ & $\begin{array}{l}\text { Pueblo, CO } \\
38.27^{\circ} \mathrm{N} ; 104.62^{\circ} \mathrm{W} \\
\text { Elev. } 1421 \mathrm{~m} \\
1999\end{array}$ & $\begin{array}{l}\text { Seymour, TX } \\
33.35^{\circ} \mathrm{N} ; 99.16^{\circ} \mathrm{W} \\
\text { Elev. } 394 \mathrm{~m} \\
2001\end{array}$ & $\begin{array}{l}\text { Temple, TX } \\
31.10^{\circ} \mathrm{N} ; 97.36^{\circ} \mathrm{W} \\
\text { Elev. } 206 \mathrm{~m} \\
1999\end{array}$ & \\
\hline April 24 & 13:53 & $13: 58$ & $13: 32$ & $13: 18$ & $13: 12$ & \\
\hline May 8 & $14: 30$ & $14: 35$ & $14: 02$ & $13: 43$ & $13: 34$ & \multirow{3}{*}{$\begin{array}{l}\text { Approx. emergence of } \\
\text { overwintering adults } \\
\text { (or addition of eggs/larvae } \\
\text { in Texas) }\end{array}$} \\
\hline May 17 & $14: 50$ & $14: 56$ & $14: 18$ & $13: 38$ & $13: 46$ & \\
\hline May 24 & $15: 04$ & $15: 10$ & $14: 29$ & $14: 05$ & $13: 55$ & \\
\hline June 1 & $15: 16$ & $15: 23$ & $14: 39$ & $14: 13$ & $14: 02$ & \\
\hline June 15 & $15: 29$ & $15: 35$ & $14: 48$ & $14: 21$ & $14: 10$ & \multirow{2}{*}{$\begin{array}{l}\text { Approx. emergence of } 1 \text { st } \\
\text { generation adults }\end{array}$} \\
\hline June 25 & $15: 30$ & $15: 35$ & $14: 50$ & $14: 21$ & $14: 10$ & \\
\hline July 4 & $15: 25$ & $15: 29$ & $14: 45$ & $14: 18$ & $14: 07$ & \\
\hline July 13 & $15: 14$ & $15: 18$ & $14: 36$ & $14: 11$ & $14: 00$ & \multirow{2}{*}{$\begin{array}{l}\text { Critical photoperiod inducing } \\
\text { reproductive diapause }^{\mathrm{b}}\end{array}$} \\
\hline July 25 & $14: 53$ & $14: 55$ & $14: 20$ & $13: 56$ & $13: 48$ & \\
\hline July 29 & 14:44 & $14: 46$ & $14: 13$ & $13: 52$ & $13: 43$ & \multirow{3}{*}{$\begin{array}{l}\text { Approx. emergence of } 2 \text { nd } \\
\text { generation adults, these go into } \\
\text { overwintering at North } \\
\text { American sites }\end{array}$} \\
\hline August 4 & $14: 30$ & $14: 32$ & $14: 02$ & $13: 43$ & $13: 34$ & \\
\hline August 8 & $14: 21$ & $14: 21$ & $13: 54$ & $13: 36$ & $13: 28$ & \\
\hline August 19 & $13: 51$ & $13: 52$ & $13: 31$ & $13: 16$ & $13: 10$ & \\
\hline August 27 & $13: 29$ & $13: 28$ & $13: 13$ & 13:01 & $12: 57$ & \\
\hline September 8 & $12: 53^{c}$ & $12: 52$ & $12: 44$ & $12: 38$ & $12: 35$ & \\
\hline September 15 & $12: 32$ & $12: 30$ & $12: 27$ & $12: 23$ & $12: 22$ & \\
\hline October 1 & $11: 45$ & $11: 41$ & 11:48 & $11: 50$ & $11: 52$ & \\
\hline
\end{tabular}


tered in field cages at the research locations in Pueblo, Colorado; Lovell, Wyoming; Delta, Utah; Lovelock and Schurz, Nevada; and Bishop, California. At these locations, overwintering adults emerged between 24 April and 8 May in 2001. First-generation adults emerged in lateJune to mid-July within field cages in Pueblo and Lovell and second-generation adults emerged from 19 August to 8 September, and these adults overwintered (Table 6).

$\mathrm{Li}$ et al. (2000) reported three generations for this insect at Fukang, China (elevation of $552 \mathrm{~m}$ ) (Table 6). This location is near the same latitude as the Wyoming site, but in Wyoming the elevation is about $600 \mathrm{~m}$ higher and average daily temperatures in late April are significantly colder $\left(13.5^{\circ} \mathrm{C}\right)$ than at Fukang $\left(22.6^{\circ} \mathrm{C}\right)$. These warmer temperatures allow the population at Fukang to begin producing eggs about a month earlier than the beetles in Wyoming (Table 3), so that a 3rd generation of adults is able to develop. We anticipate that Diorhabda populations present at similar latitudes, moderate temperatures, and low altitudes in the United States (e.g., Northern California and Oregon), also would have three generations. Sha and Yibulayin (1993) report four generations of $D$. e. deserticola at Turpan, China which is at $3 \mathrm{~m}$ elevation and latitude $42^{\circ} \mathrm{N}$. In the more southern areas of the United States, the growing season is sufficiently long to allow three or four generations if the beetles did not begin diapausing prematurely (see Diapause studies discussion below).

Diapause studies. Recently emerged 2nd generation adults held in field cages at Temple during August 1999 failed to oviposit and soon disappeared from Tamarix foliage. The following experiments were conducted to determine if short daylength was inducing reproductive diapause.

In the first test we switched adults from short to long daylength, and vice versa. Nonovipositing beetles reared in field cages were collected on 10 September, 1999 and then exposed in the laboratory to continuous light. These adults began to feed and laid eggs after 7-10 days and continued to oviposit for up to a month before observations were stopped (Fig. 3). The subset of beetles that remained outside (less than $13 \mathrm{~h}$ daylength) did not lay eggs and were never observed on the plants. The third group of adults that were actively laying eggs in the constant light and temperature conditions in the laboratory and then exposed to the short daylength in the outside cages, ceased laying eggs after 5-7 days (Fig. 3). Beetles that had remained in the laboratory from which this group was taken continued egg-laying well beyond 21 September, but numbers of eggs were not recorded. Outdoor conditions at Temple during late August and early September, when daylength is less than $13 \mathrm{~h}$, apparently induce diapause and this diapause can be reversed following exposure to $24 \mathrm{~h}$ light in the laboratory.

The second test was a comparison of survival and oviposition at short and long daylengths between groups of beetles in outdoor field cages with that of beetles held in a laboratory with a 16-h photoperiod (Fig. 4). Daylength outdoors at the start of the test was $13 \mathrm{~h} 55 \mathrm{~min}$ and had decreased to $12 \mathrm{~h} 15 \mathrm{~min}$ by the time the test ended. The mean number of eggs per female per day was significantly less for beetles held outdoors on four sampling dates during late July and early August (days 8-20) as compared to indoor females (Fig. 4A). Overall, indoor

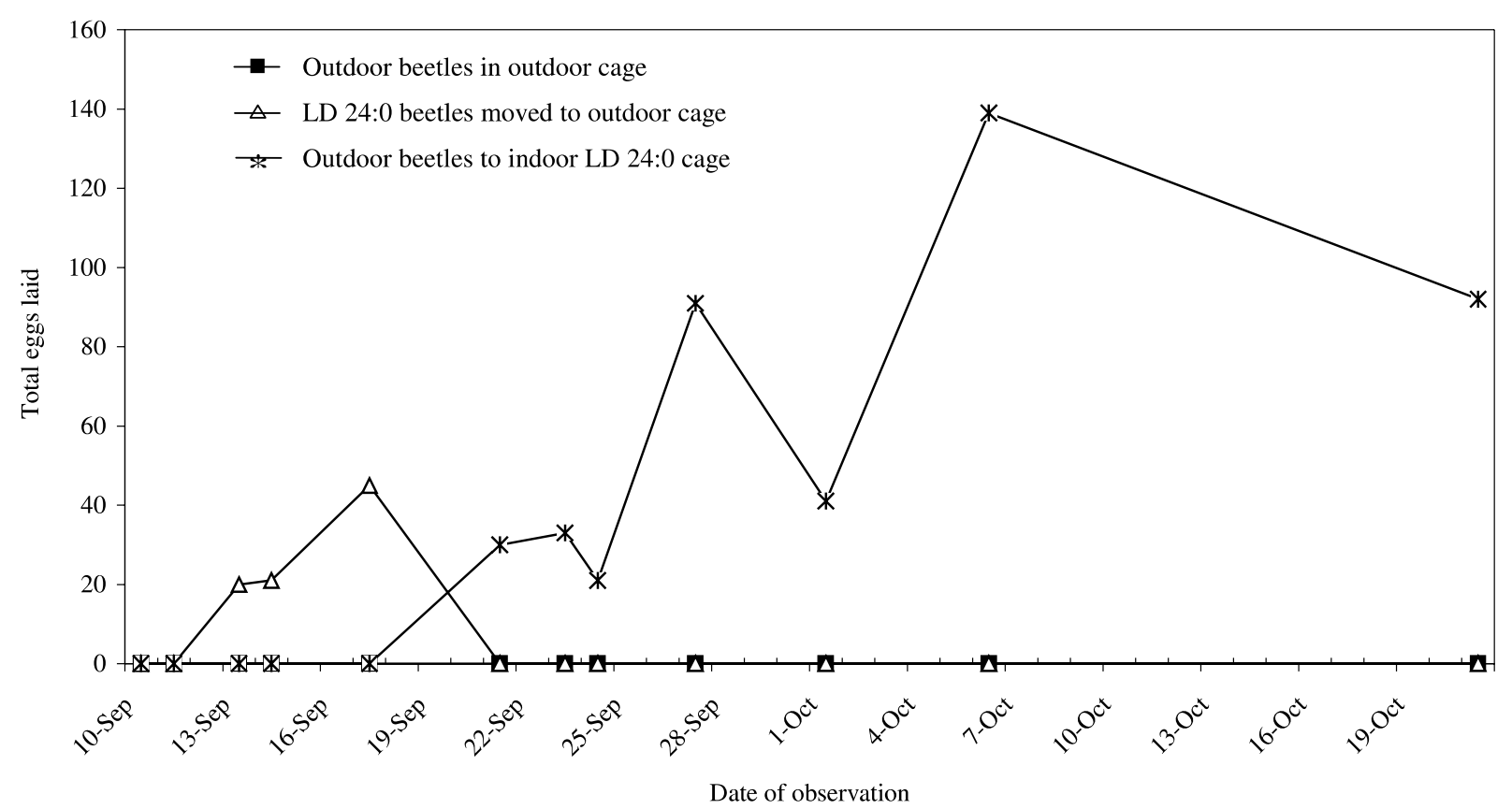

Fig. 3. Initiation and termination of egg-laying by female D. e. deserticola through exposure to either a short or a long photoperiod (numbers of insects ranged from 24 to 26 unsexed adults for each group), Temple, TX, 1999. 

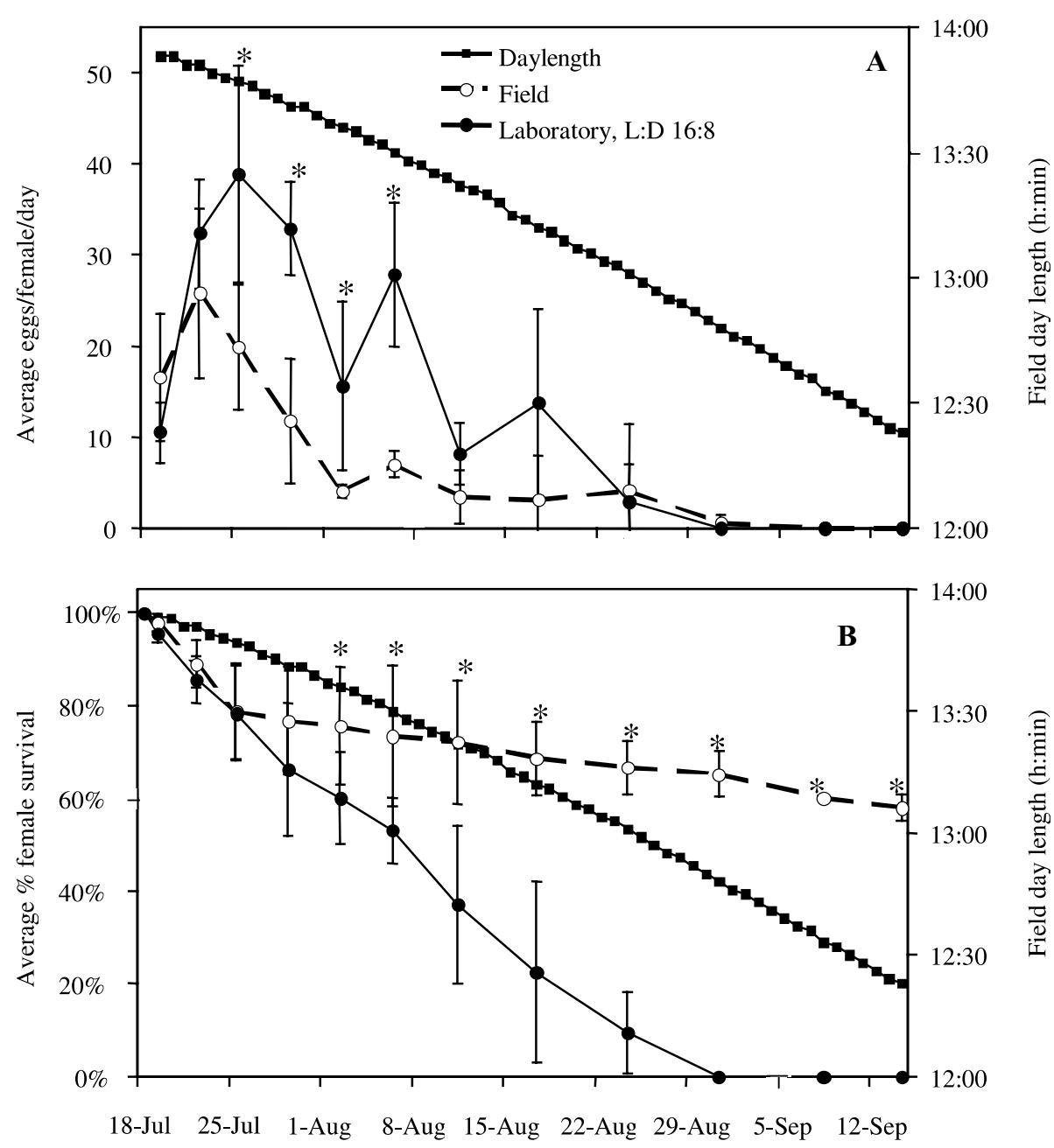

Date of observation

Fig. 4. Means $( \pm \mathrm{SD})$ values for number of eggs laid per female per day (A) and adult female survival (B) over time for 3 groups of 10 female/male pairs of D. e. deserticola held either in field cages or under constant laboratory conditions and $16 \mathrm{~h}$ light. Dates where ranks of treatments differ significantly are denoted by an asterisk $(P<0.05$; two-way Kruskal-Wallis test; SAS Institute, 1990).

females laid twice as many eggs as the outdoor females $(P<0.05$, Independent Samples $t$ test $)$, but egg-laying events, or number of egg clusters, did not significantly differ between the two groups. Outdoor females continued ovipositing at a reduced rate as late as 31 August (day 45). Survival of beetles under outdoor conditions was significantly greater as compared to beetles held in the laboratory from 6 August (day 20) onwards (Fig. 4B).

Since the beetles used in this test developed under a long daylength in Colorado, females were physiologically prepared to lay eggs and continued to do so even when exposed to the much shorter photoperiod outdoors at Temple. Females that were maintained under the long light cycle in the laboratory laid their stores of eggs and perished rather quickly. In contrast, females exposed to a short photoperiod laid fewer eggs and lived much longer, indicating a diapause condition in preparation for overwintering. The daylength outdoors at
Temple in July is comparable to that experienced by the succeeding generation in Colorado. That generation of beetles emerged around 19 August when the photoperiod was $13.5 \mathrm{~h}$ (Table 6). The temperature conditions outside during the study were more extreme than the cooler and constant indoor temperatures, so a controlled test in growth chambers is necessary to verify that decreasing daylength (or a daylength below a fixed level) is a factor that influences the longevity and egg production of these beetles.

In the third test, we observed male and female pairs placed in individual mesh bags on Tamarix branches on 26 June at Seymour, Texas. On 11 July, one or both adults were alive in 19 of the 20 adult pairs, but no eggs were present in any of the 20 mesh bags. A number of the males and females had swollen abdomens, indicative of enlarged fat bodies associated with diapause. When we inspected the bags again on 24 July, we found 14 
bags with one or both adults alive, but no eggs were present in any of the bags. On this date, 10 of the male/ female pairs were brought to the quarantine laboratory at Temple and exposed to $16 \mathrm{~h}$ light. Two females were dissected, revealing a large amount of fat body, reduced ovaries, and no developing eggs, suggesting a diapause condition. With exposure to long light conditions, six of the remaining females began ovipositing one month later on 24 August, laying an average of 135 eggs each. One ovipositing female survived until 19 October. Of the pairs remaining in the field, all but one male had died by 9 August and no eggs were present in the mesh bags.

Adults used in this test had developed from eggs laid in the Seymour field cage during May and June, where the maximum daylength was $14 \mathrm{~h} 21$ min (Table 6). The absence of oviposition by these adult females in June and July suggests that a daylength of $14 \mathrm{~h} 21 \mathrm{~min}$ will induce reproductive diapause. However, diapause could be reversed in ca. 1 month if beetles are held under long photoperiods in the laboratory. This observation is consistent with the two tests just discussed, which observed diapause at daylengths between 12 and $14 \mathrm{~h}$, and breaking of diapause with at least $16 \mathrm{~h}$ of light (Figs. 3 and 4). Our results are also consistent with detailed laboratory studies being conducted by our collaborator Daniel W. Bean (University of California at Davis, personal communication). He found the critical photoperiod inducing diapause in $50 \%$ of the population of $D$. e. deserticola collected from Fukang, China was ca. $14.75 \mathrm{~h}$ at $29^{\circ} \mathrm{C}$ and that the late-stage larva is most sensitive to photoperiod. A photoperiod as little as 15 min shorter than $14.75 \mathrm{~h}$ can result in close to $100 \%$ reproductive diapause, and the critical photoperiod becomes shorter as temperature increases.

Some larvae developed in the field in Texas under daylength well below the critical photoperiod, yet produced adults that oviposited. Adults in mid-May at Seymour oviposited and produced a generation that was in reproductive diapause (Table 6). The ovipositing adults developed from 2 nd and 3rd instar larvae that were initially reared under $16 \mathrm{~h}$ of light in the laboratory before being released as larvae in the field cage. Similarly, at Temple a small percentage of adults that emerged in late June in 1999 (daylength $14 \mathrm{~h} 10 \mathrm{~min}$ ) oviposited, producing ca. 400 progeny (Table 6). Following 2 years of observations, Daniel Bean (personal communication) found that $2-11 \%$ of adults were reproductive in the field under a daylength of $14 \mathrm{~h} 18 \mathrm{~min}$ in California. Also, overwintering adults received at Temple in late May did not appear to be photoperiod sensitive as they readily laid eggs after a period of feeding on saltcedar.

The daylength and population milestones of $D$. $e$. deserticola from four United States research locations and the research and collection site in China are given in Table 6. Except for the Texas locations, in the United
States, 2nd generation adults emerge in early September and then apparently enter diapause and overwinter. Second generation adults emerging in field cages during late-June at Seymour are exposed to a daylength well below the critical photoperiod of $14.75 \mathrm{~h}$. In fact, daylength never reaches this length at our Texas locations (Table 6). As a result, beetle populations will enter diapause in late June despite adequate heat units and abundant foliage sufficient to complete a $3 \mathrm{rd}$ and possibly a 4th generation.

Overwintering. From information provided by our cooperators, adult $D$. e. deserticola successfully overwintered in field cages in Colorado, Wyoming, Utah, Nevada, and California during three winters, from 1999 to 2002. At the Colorado site, beetles have overwintered for 4 successive winters, from 1998 to 2002. At all six locations, beetles emerged from overwintering over a period of 3 or 4 weeks, with most emerging about 2 weeks after the first adults were observed. In 2000, initial beetle emergence from overwintering ranged from 24 April to 8 May at all five locations and was not correlated with latitude, as beetles in central Colorado and at the site in Northern Wyoming emerged about 10 days before the beetles in Utah. Emergence dates in 2001 were more variable and ranged from mid-April to mid-May due to more extreme weather and/or colder spring temperatures at some locations. The date of emergence corresponded generally with the time the new shoots on saltcedar were ca. Two-three centimeters long. The beetles at first appeared sluggish, but after a few days began feeding and mating and the females began actively laying eggs. These overwintered adults lived for a period of 4-6 weeks and laid large numbers of eggs. Similarly, overwintering adults near Fukang, China typically emerge from the leaf litter and detritus at the base of saltcedar trees in the spring from mid- to late-April and lay eggs for a month before dying ( $\mathrm{Li}$ et al., 2000).

Spring emergence dates probably are influenced by temperature rather than photoperiod. As with many diapausing insects, $D$. e. deserticola adults probably emerge in the spring in response to warmer temperatures and are insensitive to photoperiod, having completed the physiological requirements for diapause in early winter (Tauber et al., 1986).

Early entry into diapause (see previous discussion in Diapause studies) may explain why adults did not overwinter successfully in field cages at Temple and Seymour during four winters (1998-2002), except for a single male noted in late March of 2000. Exposure of diapausing adults to hot conditions during August and September and mild conditions in the winter months in Central Texas may increase mortality of diapausing beetles, relative to northern locations (Colorado and Wyoming) with cooler temperatures. An important source of mortality in Texas is likely the depletion of metabolic reserves and starvation during the 7-8 months 
between early August and the first flush of Tamarix growth in Texas in early March.

Damage to saltcedar in field cages. Diorhabda e. deserticola are capable of rapid population increase and can cause significant damage to saltcedar plants. Damage within research field cages was observed by us at Temple, Dallas, and Seymour, Texas and by our cooperators in Colorado, Wyoming, Utah, Nevada, and California. We found that populations rapidly increased during the summer of 2000 and caused from 60 to $99 \%$ defoliation, with many larvae and adults dying of starvation due to lack of food inside the closed cages. The actual rate of increase by beetle populations in these cages could not be accurately calculated because of the limited food resources and difficulty of counting the large numbers, but an estimated 2-25-fold increase occurred between the number that entered overwintering sites in the fall of 2000 and the number that emerged from overwintering in the spring of 2001.

The feeding behavior of D. e. deserticola resulted in the destruction of most or all of the foliage in our field cages, but often with substantial amounts of dead foliage still hanging on the plants. This was probably because of feeding that girdled the twigs. However, even though all or nearly all foliage was dead, new buds and shoots often emerged before the next generation larvae were large enough to destroy them. Although saltcedar recovers well from defoliation, the intensive herbivory in some of the research cages has resulted in substantial dieback of stems, death of small plants, or in very limited regrowth during the following spring. At our more southern locations at Temple and Seymour, a great amount of regrowth occurred after the 2nd generation in July, since beetles then went into reproductive diapause. Nevertheless, substantial dieback of terminals occurred on the plants.

Results in field-cage studies by our cooperators at locations north of $38^{\circ}$ latitude (Colorado, Wyoming, Utah, Nevada, and California) indicated that D. e. deserticola from Fukang, China and Chilik, Kazakhstan overwinter as adults and were active throughout most of the growing season. In these areas, $D$. e. deserticola has the potential to provide good control of saltcedar. However, D. e. deserticola from Fukang did not overwinter at two locations in Texas, possibly due to the early induction of reproductive diapause in response to short daylength (less than $14 \mathrm{~h} 22 \mathrm{~min}$ ). Studies currently underway indicate the critical photoperiod is much lower for D. e. deserticola collected from sites at lower elevations in Northern China (Turpan) and for $D$. $e$. elongata from the Mediterranean region (Crete), the latter from the same latitude as north Texas. We anticipate that the identification of biotypes of $D$. e. deserticola that continue to reproduce under the short daylengths in Texas will result in successful overwintering here. Multiple generations in southern areas of the United States would greatly enhance the potential of this insect to control saltcedar in areas where it has formed dominant monocultures.

\section{Acknowledgments}

We thank Igor Lopatin (Byelorussian University, Minsk, Belarus), Alexander Konstantinov (USDA-Systematic Entomology Laboratory (SEL), Beltsville, MD), and Shawn Clark (West Virginia Department of Agriculture, Charleston, WV) for identification of the leaf beetles. We also thank Thomas Robbins (USDA-ARS, Temple, TX) for taxonomic descriptions included herein, and him and Joye Johnson for assistance with some of the experiments. We thank the following managers from the proposed release sites in the Western United States for preliminary information on overwintering and behavior in the field cages: Debra Eberts (USDI Bureau of Reclamation's, Ecological Research and Investigations Group, Pueblo, CO); David Kazmer (Department of Entomology, University of Wyoming, Laramie, WY); Greg Abbott (USDA-APHIS-PPQ, Richfield, UT); Jeff Knight (Nevada Department of Agriculture, Reno, NV); Raymond Carruthers and John Herr (USDA-ARS, Albany, CA); and Tom Dudley (Department of Entomology, University of California, Berkeley, CA). We thank Daniel Bean, Department of Vegetable Crops, University California, Davis, for providing us with preliminary information from his investigation on diapause of this beetle.

We are indebted to a number of people for providing photographs: a special thanks to Debra Eberts for providing Figs. 1A\&G, Shirlee Meola, USDA-ARSSPARC College Station, TX for the SEM shots, Roman Jashenko, Institute of Zoology, Kazakhstan Academy of Sciences, Almaty for Figs. $1 \mathrm{~B}$ and $\mathrm{E}$, and Bob Richard, USDA-APHIS, Bozeman, MT for Fig. 1F.

\section{References}

Arnold, C.Y., 1960. Maximum-minimum temperatures as a basis for computing heat units. J. Am. Soc. Hortic. Sci. 76, 682-692.

Anderson, B.W., Ohmart, R.D., 1977. Vegetation structure and bird use in the Lower Colorado River Valley. In: Johnson, R.R., Jones, D.A. (Tech Coord.), Importance Preservation and Management of Riparian Habitat: A Symposium. Tucson, AZ. USDA Forest Service, Rocky Mountain Forest Range Experiment Station, General Tech. Report RM-43. Fort Collins, CO, pp. 23-34.

Bao, P., 1989. Occurrence pattern of Diorhabda elongata deserticola Chen and its control in Erjina County. J. Pratacult. Sci. 6, 45-45 (in Chinese)

Birch, L.C., 1948. The intrinsic rate of natural increase of an insect population. J. Anim. Ecol. 17, 15-26.

Brown, B., Ruffner, G., Johnson, R., Horton, J., Franson, J., 1989. Economic analysis of harmful and beneficial aspects of saltcedar. Final Rept. to USDI Bur. Reclam., Lower Colorado Reg. Off., Boulder City, NV, Prepared by Great Western Research, Inc., Mesa, AZ.

Brullé, A., 1832. Expedition scientifique de Morée. Volume III, Part 2, Zoologique (Paris) 266, 271, tab. 44, figure 10. (in French). 
Chen, S.H., 1961. New species of Chinese Chrysomelidae. Acta Ent. Sinica 10, 431-435.

DeLoach, C.J., 1989. Prospects for biological control of saltcedar (Tamarix spp.) in riparian habitats of the southwestern United States. In: Delfosse, E.S. (Ed.), Proceedings of the 7th International Symposium of Biological Control of Weeds, March 1988. Istituto Spermiental per la Patologia Vegetale, MAF, Rome, Italy, pp. 307314.

DeLoach, C.J., Carruthers, R.I., Lovich, J.E., Dudley, T.L., Smith, S.D., 2000. Ecological interactions in the biological control of saltcedar (Tamarix spp.) in the United States: toward a new understanding. In: Spencer, N.R. (Ed.), Proceedings of the X International Symposium on Biological Control Weeds, 4-14 July 1999. Montana Statue University, MT, pp. 819-873.

DeLoach, C.J., Gerling, D., Fornasari, L., Sobhian, R., Myartseva, S., Mityaev, I.D., Lu, Q.G., Tracy, J.L., Wang, R., Wang, J.F., Kirk, A., Pemberton, R.W., Chikatunov, V., Jashenko, R.V., Johnson, J.E., Zeng, H., Jiang, S.L., Liu, M.T., Liu, A.P., Cisneroz, J., 1996. Biological control programme against saltcedar (Tamarix spp.) in the US: progress and problems. In: Moran, V.C., Hoffman, J.H. (Eds.), Proceedings of the 9th International Symposium of Biological Control of Weeds, Stellenbosch, January 1996. University of Cape Town, Cape Town, South Africa, pp. 253-260.

DeLoach, C.J., Lewis, P.A., Carruthers, R.I., Herr, J.C., Tracy, J.L., Johnson, J., 2003. Host specificity of a leafbeetle, Diorhabda elongata deserticola (Coleoptera: Chrysomelidae) from Asia, for biological control of saltcedars (Tamarix: Tamaricaceae) in the western United States. Biol. Control 22, 117-147.

DeLoach, C.J., Tracy, J.L., 1997. Effects of Biological Control of Saltcedar (Tamarix ramosissima) on Endangered Species: Draft Biological Assessment, 17 October 1997. USDA/ARS, 808 E. Blackland Rd., Temple, TX 76502.

Dudley, T.L., DeLoach, C.J., Lovich, J.E., Carruthers, R.I., 2000. Saltcedar invasion of western riparian areas: impacts and new prospects for control. In: McCabe, R.E., Loos, S.E. (Eds.), Transactions of the 65th North American Wildlife \& Natural Resources Conference, 24-28 March 2000, Chicago, IL. Wildlife Management Institute, Washington, DC, pp. 345-381.

Gerling, D., Kugler, J., 1973. Evaluation of enemies of noxious plants in Israel as potential agents for the biological control of weeds. USDA Agricultural Research Service, P.L. 480 (Project \#A10ENT-36) Final Technical Report, 1 Sept. 1970-31 Aug. 1973. Tel Aviv University, Department of Zoology, Tel Aviv, Israel. USDA/ ARS, 808 E. Blackland Rd., Temple, TX 76502.

Habib, R., Hasan, S.A., 1982. Insect enemies attacking Tamarisk, Tamarix spp., in Pakistan: Final Report, 1975-1980. Commonwealth Institute of Biol. Control, Pakistan Station, Rawalpindi, Pakistan. USDA/ARS, 808 E. Blackland Rd., Temple, TX 76502.

Hunter, W.C., 1984. Status of nine bird species of special concern along the Colorado River. Wildlife Branch Administrative Report No. 84-2. Federal Aid in Wildlife Restoration Project W-65-R-1 (554), Nongame Wildlife Investigation; California Department of Fish and Game, Resources Agency. University of California, Davis, Wildlife Extension. USDA/ARS, 808 E. Blackland Rd., Temple, TX 76502.

Johns, E.L., 1989. Water Use by Naturally Occurring Vegetation, Including an Annotated Bibliography. Amer. Soc. of Civil Engineers, New York, NY.

King, J.E., Price, R.G., Young, J.H., Willson, L.J., Pinkston, K.N., 1985. Influence of temperature on development and survival of the immature stages of the elm leaf beetle, Pyrrhalta luteola (Muller) (Coleoptera: Chrysomelidae). Environ. Entomol. 14, 272-274

Kovalev, O.V., 1995. Co-evolution of the Tamarisks (Tamaricaceae) and Pest Arthropods (Insecta; Arachnida: Acarina) with special reference to biological control prospects. In: Proceedings of Zool. Insti., Russian Academy of Sciences, St. Petersburg, vol. 259. Pensoft Publishers, Moscow.

Laboissière, V., 1934. Galerucinae de la faune Francaise (Coléoptères). Ann. Soc. Ent. France 103, 1-108.

Lewis, P.A., DeLoach, C.J., Herr, J.C., Dudley, T.L., Carruthers, R.I., 2003. Assessment of risk to native Frankenia shrubs from an Asian leaf beetle, Diorhabda elongata deserticola, (Coleoptera: Chrysomelidae) introduced for biological control of saltcedars (Tamarix spp.) in the western United States. Biol. Control 27, 148-166.

Li, B., Kong, X., Meng, L., 2000. An observation on the life cycle of Diorhabda elongata deserticola Chen: a potential biocontrol agent of saltcedar. Chinese J. Biol. Control 16, 48-49.

Lopatin, I.K., 1977. The Leaf-Beetles of Middle Asia and Kazakhstan. Nauka Publishing, Leningrad. (1984 English translation from the Russian, Amerind Publishing Company, New Delhi).

Luck, R.F., Scriven, G.T., 1976. The elm leaf beetle, Pyrrhalta luteola, in southern California: its pattern of increase and its control by introduced parasites. Econ. Entomol. 5, 409416.

Medvedev, L.N., Voronova, N.V., 1977. Survey of the species of the genus Diorhabda of the MPR fauna. In: Lavrenko, E.M., Davazhamts, Ts., Vipper, P.B., Banzragch, D., Medvedev, L.N., Bannikova, I.A. (Eds.), Biological Resources and Natural Conditions of the Mongolian People's Republic. Vegetative and Animal World of Mongolia, vol. 7. Trudy Sovm. Sov.-Mong. Kompl. Biol. Eksped, Leningrad. Nauka Publishers, Leningrad, pp. 236-244 (in Russian).

Mityaev, I.D., 1958. A review of insect pests of Tamarix in the Balkhash-Alakul depression. Trudy Inst. Zool. Akad. Nauk Kazakh. SSR 8, 74-97 (in Russian).

Mityaev, I.D., Jashenko, R.V., 1998. Biological control of Tamarix. Annual Report. Laboratory of Entomology, Institute of Zoology, Almaty, Kazakhstan.

Norusis, M.J., 1988. SPSS/PC+ V2.0 Base Manual. SPSS Inc., Chicago, IL.

Ogloblin, D.A., 1936. In: Chrysomelidae, Galerucinae. Fauna of Russia: Insects, Coleoptera, vol. 26. Institute of Zoology, Russian Academy of Sciences, Moscow, USSR (in Russian).

Pemberton, R.W., Hoover, E.M., 1980. Insects associated with wild plants in Europe and the Middle East: Biological Control of Weeds Surveys. USDA Miscellaneous Publication No. 1382. U.S. Govt. Printing Office, Washington, DC.

SAS Institute, 1990. SAS/STAT User's Guide, vol. 2/ GLM-VARCOMP. SAS Institute, Cary, NC.

Sha, P., Yibulayin, W., 1993. Preliminary study on Diorhabda elongata deserticola Chen: biological characteristics and control methods. Xinjiang Forest. Sci. Technol. J. 1, 7-10 (in Chinese).

Sinadsky, Y.V., 1968. Dendrophilous Insects of Middle Asian and Kazakhstan Deserts and Pest Management. Nauka Publishing House, Moscow (in Russian).

Tauber, M.J., Tauber, C.A., Masaki, S., 1986. Seasonal Adaptations of Insects. Oxford University Press, New York, 411 pp.

Tian, C., Zhao, L., He, D., 1988. Biology and control of three leaf beetles in rangeland. Grassland of China 5, 24-27 (in Chinese).

Tracy, J.L., DeLoach, C.J., 1999. Biological control of saltcedar in the United States: progress and projected ecological effects. In: Bell, C.E. (Ed.), Arundo and Saltcedar Management Workshop Proceedings, Ontario, California, June 1998. University of California Cooperative Extension, Holtville, California, pp. 111-154.

Warren, D.K., Turner, R.M., 1975. Saltcedar (Tamarix chinensis) seed production, seedling establishment, and response to inundation. Arizona Acad. Sci. 10, 135-144.

Zavaleta, E., 2000. The economic value of controlling an invasive shrub. Ambio 29, 462-467.

Zocchi, R., 1971. Contributo alla conoscenza dell'entomofauna delle tamerici i Italia. Redia 52, 31-129. 